\title{
The Urgency of Smart City Regulations to Accelerate Sustainable Development in Indonesia
}

\author{
Anggita Doramia Lumbanraja ${ }^{1 *}$ \\ \{anggitalumbanraja@live.undip.ac.id $\left.{ }^{*}\right\}$ \\ Fakultas Hukum, Universitas Diponegoro, Jl. Prof. H. Soedarto, S.H., Semarang, Indonesia $50275^{1}$

\begin{abstract}
To achieve Sustainable Development Goals, Indonesia can apply the concept of smart city as a solution to the shifting primarily rural to a primarily urban population. However, until now, Indonesia has not had any legal regulations that specifically regulate Smart City. This study examines the urgency of the legal basis governing smart cities in Indonesia in accelerating sustainable development in Indonesia. Researchers found that the absence of legal regulations hampered the development of smart cities in Indonesia. Legal regulations legitimize smart cities as a policy that must be obeyed, measured and directed. So, if there is a change of leadership both at the central and regional levels, the Smart Cities policy will continue. This is even more urgent when Indonesia, as dominated civil law system country, has substantial strength to legally bind smart city regulations as a legal basis for policy-making.
\end{abstract}

Keywords: Smart City; Indonesia Regulations; Sustainable Development.

\section{Introduction}

Indonesia is one of many countries that signed the Sustainable Development Goals (SDGs) Declaration. SDGs are a global action plan to end poverty, reduce inequality, and protect the environment. The SDGs contain 17 Objectives and 169 Targets which are expected to be achieved by 2030 [1]. Smart city could be a solution in achieving Sustainable Development Goals, especially at point 11 (eleven) of SDG. To be able to apply the Smart Cities Concept, there are 8 (eight) factors that need attention, i.e.: management and organization, technology, governance, policy context, people and communities, economy, built infrastructure, and natural environment [2].

Smart City is an urban system that uses information and communication technology (ICT) as capital for infrastructure and makes public services more interactive, more accessible and more efficient. Smart City give concern on the environment issues, culture and historical elements, and where its infrastructure is equipped with the most sophisticated technology solutions to facilitate the interaction of citizens with urban elements [3]. The smart cities aim is to improve the lives of citizens and manage city resources and provide better public services, improve governance, and create more resilient critical infrastructure. [4].

The shift in the social pattern in Indonesia from primarily rural to a primarily urban population [2], causing the needs of human in societies increased and more complex. Innovation and transformation are needed to meet the needs of societies. Indonesia has implemented smart cities concepts to seventy-five cities. They are twenty-four cities in the first phase and fifty cities in the second phase. They are part of the Indonesia Movement of 
100 Smart Cities that was initiated by the Ministry of Communication and Information of the Republic of Indonesia in 2017 and 2018 [5].

However, the challenging problem that has to be faced by Indonesia is the continuality of the smart cities concept in various cities constrained by the absence of legal regulations. The absence of legal regulations makes the concept of smart city unclear in its implementation and is not measurable in terms of its policies. It is difficult to implement sustainable development within the framework of the concept of smart city if there is no legal regulation.

This study examines the urgency of the existence of legal regulation on smart cities in Indonesia in accelerating sustainable development in Indonesia.

\section{Material and Method}

This research uses Doctrinal methodology (Research in Law) with Literature Study. The author collect expository materials and secondary data material from legislation, journals, textbooks, reports, conventions, and statutes related to Smart Cities and Sustainable Development Goals (SDGs).

\section{Results and Discussion}

Human development in Indonesia has been growing increasingly as seen in Figure 1. Based on data from the Indonesian Central Statistics Agency, in 2019, the Human Development Index (HDI) of Indonesia will reach 71.92 . This figure increased by 0.53 points or grew by $0.74 \%$ compared to 2018 . Achievement of human development is measured by taking into account three essential aspects which are long life indicator and healthy living indicator, knowledge indicator, and a decent standard of living indicator. HDI is an indicator that is used to see the development progress in the long run. There are two aspects as the highlight points to see the progress of human development. They are speed and achievement status [6]. Measurement through the Human Development Index becomes essential because it is one of the indicators of the Sustainable Development Goals, especially at the third point, the fourth point, and the eighth point. HDI is also a benchmark of development in Indonesia for the quality of human welfare in Indonesia. 


\section{Human Development Index (HDI) Indonesia 2010-2019}

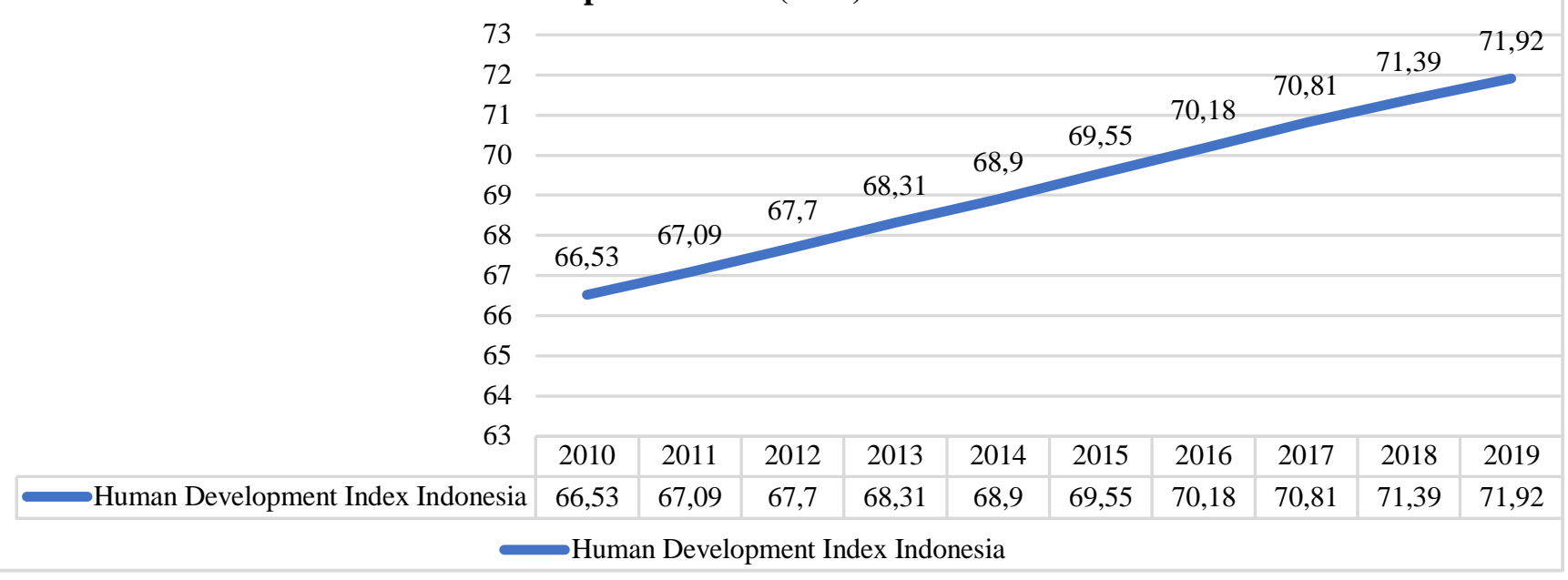

Figure 1. Human Development Index Indonesia in 2010 - 2019 [6]

According to UNDP data reports released in 2019, Indonesia is included in the High Human Development groups and took a position in 111th place in the World HGI Rank in 2018. Based on table 1, among the Southeast Asia countries, Indonesia took in the 6th place below Singapore, Brunei Darussalam, Malaysia, Thailand and the Philippines.

Table 1. UNDP Human Development Report 2019 [7].

\begin{tabular}{llccl}
\hline No & Countries & $\begin{array}{c}\text { HDI } \\
\text { Value } \\
(\mathbf{2 0 1 8})\end{array}$ & $\begin{array}{c}\text { World } \\
\text { HDI Rank }\end{array}$ & Human Development Groups \\
\hline 1 & Singapore & 0,935 & 9 & Very High Human Development \\
\hline 2 & Brunei Darussalam & 0,845 & 43 & Very High Human Development \\
\hline 3 & Malaysia & 0,804 & 61 & Very High Human Development \\
\hline 4 & Thailand & 0,765 & 77 & High Human Development \\
\hline 5 & Philippines & 0,712 & 106 & High Human Development \\
\hline 6 & Indonesia & 0,707 & 111 & High Human Development \\
\hline 7 & Vietnam & 0,693 & 118 & Medium Human Development \\
\hline 8 & Timor-Leste & 0,626 & 131 & Medium Human Development \\
\hline 9 & Lao People's & 0,604 & 140 & Medium Human Development \\
\hline 10 & Democratic Republic & & & \\
\hline 11 & Myanmar & 0,584 & 145 & Medium Human Development \\
\hline
\end{tabular}

HDI ranking has a linkage with the ranking of smart cities in the world. This is because the HDI value is one of the indicators of Smart City assessment. The IMD (the Institute for Management Development) World Competitiveness Center through the IMD-SUTD Smart City Index (SCI) assesses people's perceptions about problems related to the structure and application of technology available to them in their city. These cities are distributed into four groups based on the value of the UN Human Development Index (HDI). The ranking for each 
city is calculated from the city performance relative to other cities in the HDI group. The 102 top smart cities in the world based on the IMD World Competitiveness Center assessment data released in 2019, there are three cities in Indonesia ranked in these 102 top smart city ranking. They are Makassar, Jakarta and Medan. Indonesia is one of the five countries that ranked in the 102 top smart cities in the world based on table 2 .

Table 2. The Cities list in Southeast Asia that took place in 102 of the top smart cities in the world based on the IMD-SUTD Smart City Index (SCI) 2019 [8]

\begin{tabular}{lllcl}
\hline No & City & Country & World Ranking & Rating \\
\hline 1 & Singapore & Singapore & 1 & AAA \\
\hline 2 & Ho Chi Minh City & Vietnam & 65 & CCC \\
\hline 3 & Hanoi & Vietnam & 66 & CCC \\
\hline 4 & Kuala Lumpur & Malaysia & 70 & CCC \\
\hline 5 & Makassar & Indonesia & 80 & CC \\
\hline 6 & Jakarta & Indonesia & 81 & CC \\
\hline 7 & Medan & Indonesia & 82 & CC \\
\hline 8 & Manila & Phillipine & 94 & C \\
\hline
\end{tabular}

Indonesia, as dominated by civil law systems country, has a strong modal in stimulating the implementation of smart cities. Based on research conducted by Zakaria, monetary policy is relatively more effective in influencing output in civil-law countries than in common-law countries [9]. Indonesia, as a civil law system country, was able to survive the global economic crisis in 2008 compared to Singapore, Malaysia and Thailand. This is influenced by the policy responses and the overall political economy situation [10]. The character of a civil law system is dominated by the strength of the legally binding code of society where the legal system is in dire need of regulation [11], compared to the common law system which focuses on judge-made law [12].

Up to now, Indonesia does not yet have a legal basis for applying the concept of smart cities in Indonesia. This has become an obstacle for the implementation of the 100 national smart cities Movement. The design of the Smart City has only been legitimized as a medium long-term macro policy in the National Medium-Term Development Plan 2020-2024 prepared by the Ministry of National Development Planning/National Development Planning Agency of the Republic of Indonesia in 2019. Where the concept of smart city is now one of the urban development goals where Reliable utilization ICT in urban services as an important aspect. smart city is one of the policy targets in the 2020-2024 Medium-Term Long Plan with a Target Transformation Digital towards Indonesia Digital [13]. Meanwhile, Local Governments in Indonesia that have applied smart cities in its cities have stated smart city policies in their respective Regional Medium-Term Development Plans.

Indonesia needs to make Smart Regulations [14]. Smart Regulation may be consist of Laws of Data Protection [15], Laws of Smart Cities by including six things regulated in them, namely: Smart Living, Smart Economy, Smart People, Smart Governance, Smart Mobility and Smart Environment [16]. From the Smart City Act, it can breakdown to six government regulations governing each of these points. 
Table 3. Lists of Regulation Recommendation regarding Smart City Issue

\begin{tabular}{|c|c|c|}
\hline $\begin{array}{c}\text { Type of } \\
\text { Regulation }\end{array}$ & Laws & Government Regulations \\
\hline \multirow{8}{*}{ 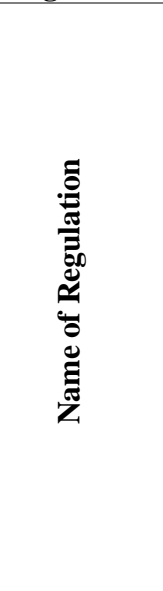 } & \multirow{6}{*}{ Laws of Smart Cities } & $\begin{array}{l}\text { Indonesia Government Regulations of } \\
\text { Smart Living }\end{array}$ \\
\hline & & $\begin{array}{l}\text { Indonesia Government Regulations of } \\
\text { Smart Economy }\end{array}$ \\
\hline & & $\begin{array}{l}\text { Indonesia Government Regulations of } \\
\text { Smart People }\end{array}$ \\
\hline & & $\begin{array}{l}\text { Indonesia Government Regulations of } \\
\text { Smart Governance }\end{array}$ \\
\hline & & $\begin{array}{l}\text { Indonesia Government Regulations of } \\
\text { Smart Mobility }\end{array}$ \\
\hline & & $\begin{array}{l}\text { Indonesia Government Regulations of } \\
\text { Smart Environment }\end{array}$ \\
\hline & \multirow{2}{*}{$\begin{array}{l}\text { Laws of Data Protection Regulation } \\
\text { (Transfer Personal Data) }\end{array}$} & $\begin{array}{l}\text { Indonesia Government Regulations of } \\
\text { Security and Privacy }\end{array}$ \\
\hline & & $\begin{array}{l}\text { Indonesia Government Regulations of } \\
\text { Transparency and modalities }\end{array}$ \\
\hline
\end{tabular}

Table 3 illustrates the draft regulatory framework needed to legitimize the implementation of smart cities in Indonesia. The making of these laws and regulations is essential because there are many obstacles that arise in Indonesia nowadays without any statutory regulations that regulate explicitly about Smart City. Substitution of leadership both at the Central and local government, can lead to discontinuity in the implementation of smart city policies. Differences in the vision of each leader must be adjusted according to the provisions of the legislation established.

Currently, there are several regions in Indonesia that are experiencing difficulties in implementing smart cities due to the change of regional leaders. The smart city concept has begun to be abandoned, such as the Qlue application that is no longer used by the local government. This has happened in Jakarta and Bandung, which have already had different governors.

Indonesia Medium-Term Development Plan 2020-2024, that stated smart cities in its policies, must be followed up with the issuance of these laws and regulations. Another urgency that arises is the plan to relocate the New Capital City to be built in the concept of smart city. To facilitate policy-makers from the central government to the local government, the existence of these laws and regulations is very urgent to be published.

\section{Conclusion}

Indonesia is one of the countries that has predicate of high human development in the HDI indexation conducted by UNDP. In the ranking conducted by the IMD in the 2019 IMDSUTD Smart City Index (SCI) there are three cities in Indonesia that are included in the world's top 102. This is because Indonesia has a policy system that supports development itself. The other hand, Indonesia has not had any smart city regulation. To implement sustainability-based policies, the 2020-2024 Medium-Term Development Plan is followed up with the issuance of laws and regulations on Smart City. This becomes important when 
Indonesia has a plan to move its capital and develop it in the concept of smart city. There are two types of laws and regulations that can stimulate sustainable development acceleration, i.e.: Laws of Smart Cities and Laws of Data Protection Regulation (Transfer Personal Data), Indonesia Government Regulations of Smart Living, Indonesia Government Regulations of Smart Economy, Indonesia Government Regulations of Smart People, Indonesia Government Regulations of Smart Governance, Indonesia Government Regulations of Smart Mobility Indonesia Government Regulations of Smart Environment, Indonesia Government Regulations of Security and Privacy, Indonesia Government Regulations of Transparency and modalities.

Acknowledgements. We are grateful to the Faculty of Law, Universitas Diponegoro, Semarang-Indonesia which fully funded this research. 


\section{References}

[1] United Nations, Transforming Our World: The 2030 Agenda For Sustainable Development. 2015.

[2] H. Chourabi, N. TAEWOO, and S. Walker, "Gil-Garcia," in JR, MELLOULI, S., NAHON, K., PARDO, T., SCHOLL, HJ: Understanding Smart Cities: An Integrative Framework. 45th Hawaii International Conference on System Science, 2012.

[3] S. Pellicer, G. Santa, A. L. Bleda, R. Maestre, A. J. Jara, and A. G. Skarmeta, "A global perspective of smart cities: A survey," in 2013 Seventh International Conference on Innovative Mobile and Internet Services in Ubiquitous Computing, 2013, pp. 439-444.

[4] S. D. Rosadi and S. A. Kristyan, "Privacy challenges in the application of smart city in Indonesia," in 2017 International Conference on Information Technology Systems and Innovation (ICITSI), 2017, pp. 405-409.

[5] R. Mahesa, G. Yudoko, and Y. Anggoro, "Dataset on the sustainable smart city development in Indonesia," Data Br., vol. 25, p. 104098, 2019.

[6] Indonesian Central Statistics Agency, Human Development Index Indonesia 2019 No. 21/02/Th. XXIII, 17 Februari 2020, 1-8 pp [in Indonesia]. pp. 1-8.

[7] United Nations Development Programs, Human Development Report 2019 Beyond income, beyond averages, beyond today: Inequalities in human development in the 21st century. New York, 2019.

[8] Institute for Management Development (IMD) - World Competitiveness Center, "IMD Smart City Index 2019." [Online]. Available: https://www.imd.org/globalassets/wcc/docs/smart_city/smart_city_index_digital.pdf.

[9] Z. Zakaria, "The performance of monetary policy: A comparison between civil-law and common-law countries," J. Kemanus., vol. 5, no. 1, 2007.

[10] M. C. Basri, “A tale of two crises: Indonesia's political economy," JICA-RI Work. Pap., vol. 57, pp. 1-37, 2013.

[11] S. F. Joireman, "Colonization and the rule of law: Comparing the effectiveness of common law and civil law countries," Const. Polit. Econ., vol. 15, no. 4, pp. 315-338, 2004.

[12] A. Sanders, "The characteristic features of the Civil Law," Comp. Int. Law J. South. Africa, vol. 14, no. 2, pp. 196-207, 1981.

[13] Ministry of National Development Planning, the National Medium-Term Development Plan 2020-2024 : Indonesia has medium to high income that is Prosperous, Fair and Sustainable. Jakarta, 2019.

[14] G. G. Gasiola, J. M. Lopes, A. F. B. Junior, and E. M. Dias, "Smart Cities through Smart Regulation [Opinion]," IEEE Technol. Soc. Mag., vol. 38, no. 1, pp. 25-28, 2019.

[15] D. Lučić, M. Boban, and D. Mileta, "An impact of general data protection regulation on a smart city concept," in 2018 41st International Convention on Information and Communication Technology, Electronics and Microelectronics (MIPRO), 2018, pp. 390-394.

[16] A. Founoun and A. Hayar, "Evaluation of the concept of the smart city through local regulation and the importance of local initiative," in 2018 IEEE International Smart Cities Conference (ISC2), 2018, pp. 1-6. 